\title{
THE SOCIOECONOMIC CONDITIONS OF WASTE PICKERS IN BAHIA, AND AN EVALUATION OF A WORKFORCE RESTRUCTURING: A MULTIPLE CASE STUDY
}

\author{
Maria de Fátima Gutierrez de Almeida \\ Mestre em Gestão e Tecnologia Industrial \\ SENAI CIMATEC \\ fatimagutierrez7@gmail.com \\ Paulo S. Figueiredo \\ Doutor em Administração de Empresas \\ Universidade Federal da Bahia - UFBA \\ paulo_s_figueiredo@hotmail.com \\ Josiane Dantas \\ Doutora em Ciência e Engenharia de Materiais \\ SENAI CIMATEC \\ josianedantas@fieb.org.br
}

\begin{abstract}
The inclusion of waste pickers in the recycling supply chain in a sustainable manner, i.e., with sufficient compensation, scale, and incentives to sell at least part of waste pickers' production directly to industry, represents a major challenge in terms of organization, management, and economic-financial sustainability. The National Solid Waste Policy (PNRS) established a target date for the implementation of a selective collection system and prioritized the participation of cooperatives. The objective of this study is to propose a business model that enhances the economic benefits attained by waste pickers. Two methodologies were used: a qualitative approach based on interviews and action research. The methodology for socioeconomic analysis was qualitative and used semi-structured interviews as a research tool. The sample comprised four small cities representing the population. For the action research, visits were made to two cooperatives. In addition, meetings were held with the workers' representatives, benchmarking was performed, and a project proposal for a recyclable waste processing and selling facility (RPSF) was prepared. The proposal was based on the results of the analysis and on the law (PNRS). It is proposed that a processing and selling facility for recycled waste be created and that it be managed by a second-degree cooperative. It is estimated that the implementation of this proposal could increase the average income of waste pickers by $67.44 \%$.
\end{abstract}

Key Words: Social justice; Informal sector; Waste Picking; Recycling; Cooperatives.

\section{AS CONDIÇÕES SOCIOECONÔMICAS DOS DESPERDÍCIOS EM BAHIA E UMA AVALIAÇÃ O DE UMA REESTRUTURAÇÃO DE TRABALHADORES: UM ESTUDO DE CASO MÚLTIPLO}

\section{RESUMO}

A inclusão de catadores na cadeia de suprimento de reciclagem de forma sustentável, ou seja, com remuneração, escala e incentivos suficientes para vender, pelo menos, parte da produção de catadores diretamente à indústria, representa um grande desafio em termos de organização, E sustentabilidade econômico-financeira. A Política Nacional de Resíduos Sólidos (PNRS) estabeleceu uma data-limite para a implementação de um sistema de coleta seletiva e priorizou a participação das cooperativas. O objetivo deste estudo é propor um modelo de negócio que melhore os benefícios econômicos alcançados pelos catadores. Foram utilizadas duas metodologias: uma abordagem qualitativa baseada em entrevistas e pesquisa-ação. A metodologia de análise socioeconômica foi qualitativa e utilizou entrevistas semi-estruturadas como ferramenta de pesquisa. A amostra compreendeu quatro pequenas cidades representando a população. Para a pesquisa-ação, foram realizadas visitas a duas cooperativas. Além disso, foram realizadas reuniões com os representantes dos trabalhadores, foram efectuadas avaliações comparativas e foi elaborada uma proposta de projecto para uma instalação de processamento e venda de resíduos recicláveis (RPSF). A proposta baseouse nos resultados da análise e na lei (PNRS). Propõe-se a criação de uma unidade de transformação e venda de resíduos reciclados e a sua gestão por uma cooperativa de segundo grau. Estima-se que a implementação desta proposta poderia aumentar a renda média dos catadores em $67,44 \%$.

Palavras-chave: Justiça social; Setor informal; Colheita de resíduos; Reciclando; Cooperativas. 


\section{INTRODUCTION}

Municipal solid waste (MSW) includes domestic solid waste and urban sanitation waste (Sedur, 2014). The subject of this study is recyclable waste contained in inorganic domestic solid waste (waste derived from domestic activities in urban households) and in solid waste generated by small commercial establishments. According to a study by the Brazilian Association of Urban Cleansing and Waste Management Companies [Associação Brasileira de Empresas de Limpeza Pública e Resíduos Especiais ABRELPE] (2013), the generation of MSW in Brazil was 76,387,200 tons in 2013, which indicates that the amount of MSW generated by Brazil increased by $4.1 \%$ between 2012 and 2013. This increase is higher than the urban growth rate of 3.7\% over the same period (Abrelpe, 2012; Ibge, 2010) and made Brazil the fifthlargest producer of waste in the world. Moreover, although more than $30 \%$ of MSW has recycling potential, only $3 \%$ was effectively recycled (Abrelpe, 2013).

Brazil has a comprehensive legal enforcement policy regarding solid waste. The regulatory framework for this area is embodied in the National Solid Waste Policy (Política Nacional de Resíduos Sólidos - PNRS), which was established by Federal Act no. 12,305 of August 2, 2010 and regulated by Decree no. 7,404 of December 23, 2010. The PNRS represents a major breakthrough for solid waste management in Brazil because of its systemic approach that considers social, environmental, cultural, economic, and public health variables and because it establishes an order of priority for solid waste management, as follows: non-generation, reduction, reuse, recycling, solid waste treatment, and environmentally sound disposal (Article no. 9). Among other assumptions, the PNRS maintains that "the implementation of a selective collection system is an essential instrument for achieving the goal of environmentally sound waste disposal". The PNRS established a target date of August 2014 for the implementation of a selective collection system and prioritized the participation of cooperatives or "other types of associations of reusable and recyclable material collectors formed by low-income individuals".

The PNRS recognizes the work of waste pickers, organized as fundamental players of the Brazilian recycling chain. It demands that many business sectors use reverse logistics for solid waste that is generated by their products, emphasizing the participation of waste picking cooperatives in this process. However, the small interest of such companies in managing reverse logistics programs and the difficulties in integrating companies and cooperatives represent a challenge in fulfilling these objectives (Demajorovic et al., 2014).

Waste pickers earn a living by sorting and selling recyclable waste with market value. They are a component of the recycling supply chain and are even considered the chain's support base (Medina, 2000). Despite the importance of their work, which yields social, economic, and environmental benefits for cities, waste pickers are the least-valued workers and receive the least amount of benefits from waste picking activities (Aquino et al., 2009).

According to the aforementioned authors, nearly all cities fail to recognize that the services provided by waste pickers constitute a component of an environmentally conscious solution for solid waste disposal. In contrast, the recycling industry, the last link in the supply chain, usually purchase post-consumer waste from middlemen/intermediaries that have the infrastructure and conditions necessary to supply large volumes of waste and higher-quality waste. In general, waste pickers are scattered and do not have the necessary capabilities to trade directly with industries (Aquino et al., 2009).

The inclusion of waste pickers in the recycling supply chain in a sustainable manner, i.e., with sufficient compensation, scale, and incentives to sell at least part of waste pickers' production directly to industry, represents a major challenge in terms of organization, management, and economic-financial sustainability. According to Giovannini and Kruglianskas (2008), the recycling chain must have an economic purpose to ensure long-term sustainability.

Because solid waste generation is calculated per capita, and directly proportional to the size of the population, the effects of smaller amounts of waste and higher organic waste percentages on the total income and working conditions of waste pickers is uncertain. Moreover, it is also unclear if the resultant income and working conditions are adequate to meet basic human needs and to ensure a safe working environment. Despite more restrictive laws and efforts by all government sectors to develop better waste disposal practices, 3,344 cities (representing 60.0\% of all Brazilian cities), most of them small, continue to improperly dispose of their MSW in waste dumps and managed landfills (Abrelpe, 2013).

The new law, which mandates selective collection of waste and the extinction of waste dumps beginning in August 2014, has not been enforced effectively. According to the president of ABRELPE 
(Brazilian Association Of Urban Cleaning And Waste Management Companies), in an interview, the cities may secure "Conduct Adjustment Agreements" (Termo de Ajuste de Conduta), which significantly lengthen the period of time over which the law's provisions will take effect (Rádio Nacional de Brasília, 2015).

It can be argued that in this scenario, waste pickers are the strategic suppliers of the recycling industry; therefore, it is important to find a way to increase their economic gains and improve their working conditions.

The specific objective of this research is to propose a business model that adheres to the new legislation, enhances the economic benefits obtained by waste pickers, and improves waste pickers' working conditions. The specific objectives are as follows: (1) to characterize the current working and socioeconomic conditions of waste pickers in small cities within the study area to support the new management model and (2) to estimate the economic benefits that will be achieved with the proposed management model.

\section{LITERATURE REVIEW: THE SOCIO-ECONOMIC CONDITIONS OF WASTE PICKERS}

The literature review for this study comprised four main analytical categories: reverse logistics, the National Solid Waste Policy (PNRS), cooperatives of waste pickers, and socio-economic studies about waste picking.

One phenomena of globalization is the consumption of disposable products. In industrialized countries, there is a relative abundance of capital but relatively scarce labor, whereas in developing countries, there are large pools of unskilled and cheap labor but a relative scarcity of capital. Hence, it makes sense that industrialized countries seek cost-effective labor practices to manage solid waste, whereas in developing countries, solid waste scavenging provides a source of income for unskilled workers (Medina, 2000).

Waste pickers can be considered the lead actors in the recycling industry. They play a crucial role in solid waste management, and their very existence exemplifies the difficulty of including the waste picking activity in formal waste management systems, which is due primarily to problems relating to scale-ofproduction and logistics issues (Gonçalves-Dias, Lopes, 2009).

Demajorovic et al. (2014) studied the challenges and perspectives for the development of cooperatives of waste pickers. The authors show that the integration of companies and cooperatives has the potential to enable reverse flows and generate economical and socio-environmental benefits, especially when there is integration among companies, cooperatives and the government. Challenges such as improving managerial processes and information systems in the cooperatives, as well as difficulties to engage other suppliers of the chain, were also identified.

Jesus and Barbieri (2013) performed a multiple case study aiming to understand the participation of cooperatives of waste pickers in private reverse logistics programs. The study focused on the recycling of goods such as glass, cardboard and plastic, among others. The cooperatives work as first degree suppliers of such goods. In general, the existence of the reverse logistics programs can be explained by socioenvironmental responsibility motivations, as well as the desire by the companies to recover raw materials, competitiveness of packaging and corporate image.

Santos (2012) studied how cooperatives of waste pickers represent an alternative to reduce the environmental impact of solid waste generation. Besides, the activity represents a significant source of income to waste pickers. This study focused on the contributions made by the "Cooperativa dos Catadores de Material Recicláveis" located in Campina Grande - PB, a cooperative located in the northeast region of Brazil.

Souza et al. (2012) identified the social and environmental contribution of cooperatives of waste pickers to the reverse channels of solid waste, by means of a multiple case study. The study shows that cooperatives have an important role in collecting and recycling urban solid waste and in mitigating the environmental impact of such waste.

Afon (2012) examined the environmental, public health, economic, and social implications of closing an open waste dump in Lagos, Nigeria, and concluded that due to the amount of work generated by waste picking and the large number of individuals directly involved in the activity, the potential prohibition of waste picking without a corresponding effort to direct waste pickers to other economic activities posed a 
social, economic, and security threat to the community. The author argued that waste picking activity should be regulated and fully integrated into the waste management system. In this sense, it is important to note that although the PNRS also contemplates the eradication of dumps, it includes waste pickers in the waste management system.

Gutberlet (2007) discussed the results of studies conducted at the beginning of 2005 on the Ribeirão Pires recycling cooperative (COOPERPIRES). The study revealed the social and economic challenges of the organized group and the group's vulnerability due to its dependence on local policies. In addition, it highlighted the need for public policies related to waste management, including strategies to reduce poverty and to improve environmental health. Gutberlet (2007) emphasized the need for inclusive and participatory public policies for waste management and urged recognition of the social, economic, and environmental benefits derived from appropriate waste management policies.

Gomes and Nóbrega (2005) conducted an economic feasibility study of a program to selectively collect domestic solid waste in the city of João Pessoa, Brazil. Because of its social and environmental benefits, the program was supported by the Public Company of Urban Sanitation (Empresa Pública de Limpeza Urbana - EMLUR) in 2000. The initial goal of the program was to close an old waste dump, which was scavenged by 500 individuals, and to build a new landfill for the metropolitan region of the city. The scavengers created the Association of Recyclable Material Workers (Associação de Trabalhadores de Materiais Recicláveis - ASTRAMARE), with the support of a non-governmental agency, the Caritas Foundation of Brazil. The results showed that the feasibility rate increased by $10.8 \%$ after the Association was established, and the business was deemed viable.

Medina (2000) studied informal recycling activities (solid waste scavenging without government participation or control) performed by recycling cooperatives in Asia and Latin America. It is estimated that in some cities in these areas, approximately $2 \%$ of the population makes a living from waste scavenging. Most waste scavengers in developing countries can be considered poor, which the author argues is due in large part to the low prices paid for recyclable materials by intermediaries, who then sell the materials at high profit margins. In Mexico City, for example, scavengers sell their production to their leader, who in turn sells the materials to the industry for a profit of at least $300 \%$. As a result, waste scavengers in Mexico City usually have incomes below the minimum wage and, due to the poor working conditions, have a life expectancy of 39 years. The establishment of waste scavenging cooperatives attempts to avoid intermediaries and thereby obtain higher prices for recyclable materials collected by cooperative workers.

Medina (1998) conducted a qualitative and quantitative study on the recycling system of the neighboring cities of Nuevo Laredo, Mexico, and Laredo, Texas, and found that aluminum recovery is performed by landfill scavengers and street scavengers, as well as in homes and small businesses. This group of actors recovers approximately $75 \%$ of the cans consumed by the region's population. Aluminum recovery in the area has strong connections to the formal sector and to the international economy. In sum, this study challenges previous characterizations of waste scavengers as being poor and marginalized, although the author emphasized scavengers' unfavorable conditions (MEDINA, 1998).

Tirado-Soto \& Zamberlan (2013) discussed the role of networks formed of waste-picker cooperatives in ameliorating problems of final disposal of solid waste in the city of Rio de Janeiro. The authors presented a method for creating and structuring a network of recycling cooperatives, with prior training for working in networks, so that the expected synergies and joint efforts can lead to concrete results. Ferri et Al. (2015) propose a reverse logistics network involved in the management of municipal solid waste to solve the challenge of economically managing these wastes considering the recent legal requirements of the Brazilian Waste Management Policy. The study emphasizes the strong presence of waste pickers who, according to the authors, must be included in the system.

The following Brazilian cooperatives of solid waste pickers also exemplify successful work organizations: Waste Pickers' Network of Western São Paulo State (Rede de Catadores do Oeste Paulista) (Carvalho; Ladeia, 2011); Coopercentral (Mazzei; Crubellate, 2011); Cooperative of Waste Pickers of the Metropolitan Region of Belo Horizonte (Cooperativa de Catadores da Região Metropolitana de Belo Horizonte) (Arantes and Borges, 2013); Uniforja (Rufino, 2002); and Coopercaixa (Saraiva Júnior; Costa; Pinto, 2009). Three other cooperatives of that operate together in a network also merit attention (Inspiração Magazine, 2013): Cooperative of Ecological Agent Waste Pickers of Canabrava (Cooperativa de Catadores Agentes Ecológicos de Canabrava - CAEC), Recycling Cooperative of São José dos Campos (Cooperativa de Reciclagem Futura de São José dos Campos - FUTURA) and Solidarity Network of Sorocaba 
Cooperatives and Neighboring Regions (Rede Solidária das Cooperativas de Sorocaba e região - REDE CATA VIDA).

According to Lima (2010), the recycling cooperatives arose in Brazil due to two factors: 1) The growing importance of environmental issues, the increase in Production of urban solid waste and the necessity to reduce the environmental impacts; and 2) The restructuring of the national economy, together with the globalization of markets which created unemployment. In this context, recycling becomes economically attractive to the industries, due to the reduced cost of raw materials transformation. The author mentions as positive aspects that in some cities where the cooperatives are more organized, waste pickers are given uniforms and use proper vehicles, which increases the visibility of their activities and shows the positive nature of recycling to the population. This contributes to improve the respect of the population towards waste pickers, who were seen as beggars or criminals in the past. Besides, the waste pickers receive a fixed income when they work for the municipalities in the "solidarity picking activities" (Lima, 2010, p. 3). Solidarity Picking Activities or "Coleta Seletiva Solidária" is an initiative of the federal government that aims to build a new model for waste management in the country, establishing the waste pickers as the protagonists in the waste management activities. (Site: www.coletaseletivasolidaria.com.br).

However, Wirth (2010) singles out a a vulnerability: the diversity of actors and interests involved in policies for recycling. The waste pickers, alone or organized in groups, have to compete with the large recycling companies who use lobbying activities on municipalities in order to gain exclusive rights over the collection, selling and transformation of the solid waste. The author concludes that the cooperatives of waste pickers are situated in the middle of the productive chain, where in one extreme are the large waste collecting companies, and in the other extreme are the cartel of recycling companies and middlemen, who determine the prices paid for recyclable matter (Wirth, 2010).

Public policies are another important matter. Leite (2011) argues that in order to guarantee that the cooperatives effectively bring better economic conditions and quality of life to the waste pickers, it is necessary that the government create public policies so that the collection and handling of solid waste will be performed by the waste pickers, eliminating the activities of large companies whose business interests are potentially harmful to the interests of waste pickers (Leite, 2011).

\section{STUDY METHODS AND TECHNIQUES}

This study focuses on waste pickers in the interior of the state of Bahia, Brazil.. The methodology is composed of two parts or main activities, each of which has a multiple steps, as described below. The literature review that was performed led the authors to ponder about the financial benefits of organizing the work of waste pickers in cooperatives and about their socio-economic conditions. These are the two main areas of inquiry of this study.

\subsection{Strategy for socioeconomic analysis}

The methodology for socioeconomic analysis was qualitative and was based on semi-structured interviews. The sample comprised the four small cities representing the population.

To determine the socioeconomic conditions of reusable and recyclable material waste pickers who work in the urban areas of small cities in this region (cities with up to 20,000 inhabitants), it was decided that the spatial extent of the study would include four cities located within two "identity territories" (distinct state regions), namely, the Chapada Diamantina and the Sertão Produtivo (Seplan, 2007), and that each of the four cities would have an urban population of up to 10,000 inhabitants. Ultimately, the cities of Andaraí, Mucugê, Ituaçu, and Tanhaçu were selected.

The criteria for inclusion in the study area comprise the geographical proximity to the municipality of Mucugê, Bahia; socioeconomic similarities as indicated by the EDI, SDI, and Municipal HDI development indices (see Table 1); environmental and cultural similarities; and, most importantly, the size of the urban population.

The municipality of Mucugê stands out from the rest of the region because of the Mucugê-Ibicoara Farming Complex, which generates a significant amount of plastic packaging from pesticides, and because of the successful implementation of the Waste Recycling and Composting Plant in that municipality in 1999. 
Table 1 - Development indices of the cities studied

\begin{tabular}{llll}
\hline City & \multicolumn{2}{l}{ Development Index } & \\
& $\begin{array}{l}\text { Economic } \\
\text { (EDI) }\end{array}$ & $\begin{array}{l}\text { Social } \\
(\text { SDI) }\end{array}$ & $\begin{array}{l}\text { Municipal Human } \\
(\text { HDI) }\end{array}$ \\
\hline Andaraí & $4,980.73$ & $4,971.89$ & 0.555 \\
\hline Mucugê & $4,990.67$ & $4,978.50$ & 0.606 \\
\hline Ituaçu & $4,991.09$ & $4,990.67$ & 0.570 \\
\hline Tanhaçu & $4,989.70$ & $4,970.58$ & 0.577 \\
\hline
\end{tabular}

Source: IBGE, 2010 and SEI, 2006

All interviews were conducted face-to-face. Monitoring and direct assistance were provided by the interviewer, who read the questions to the respondent.

The questionnaire was pre-tested with 15 undergraduate students of the Senai Cimatec College of Technology to estimate the time required for completion (especially the time required to read and explain the questions to the respondents) and to determine which questions required further clarification or revision.

The questionnaire was also analyzed and validated by an agent of the Solid Waste Coordination Division of the Department of Urban Development (Secretaria de Desenvolvimento Urbano - SEDUR) of the state of Bahia.

\subsection{Proposed new waste picking workforce management model}

The action research method was used to develop a new waste picking workforce management model (Ketele; Roegiers, 1993).

Visits were made to two cooperatives: CAEC in Salvador and COOPREC in Goiânia. In addition, meetings were held with the workers' representatives, benchmarking was performed, and a project proposal for a recyclable waste processing and selling facility (RPSF) was prepared. The proposal was based on the results of the analysis and on the law; it is also compatible with waste pickers' efforts to vertically integrate the recycling supply chain.

\section{Financial return calculation}

This step entailed the calculation of the estimated financial return, i.e., the increase in the net income of individual waste pickers currently working in dumps and sorting units. The potential percentage increase in waste scavenger income derived from the processing of their collected waste using the RPSF structure was estimated.

The performance variable was calculated as price/kg. For this purpose, income from waste picking activity without processing was calculated using average market prices, as was the net income earned by the waste pickers with the new system (or RPSF profit); then, these two incomes were compared to determine the percentage increase obtained with the new system. The total percentage gain was calculated without estimating individual gains that depend on the composition and amount of waste delivered.

\section{RESULTS AND DISCUSSION}

To analyze the activities of reusable and recyclable material waste pickers and to assess waste pickers' working conditions and economic benefits, field research was conducted in the four small towns of Andaraí, Mucugê, Ituaçu, and Tanhaçu.

Out of a total of 29 waste pickers, 25 waste pickers were interviewed, none of whom worked for a cooperative or association. Most waste pickers were male, between 18 and 34 years old, and characterized by a low educational level (Table 2). 
Table 2 - Respondents' information

\begin{tabular}{|c|c|c|c|c|c|c|c|c|c|c|c|}
\hline \multirow[b]{2}{*}{ LOCATION } & \multicolumn{2}{|c|}{ Respondents } & \multicolumn{4}{|c|}{ Age } & \multicolumn{3}{|c|}{ Educational level } & \multicolumn{2}{|c|}{$\begin{array}{l}\text { Number of } \\
\text { waste pickers }\end{array}$} \\
\hline & male & female & $\begin{array}{l}< \\
18\end{array}$ & 18 to 34 & 35 to 59 & $>60$ & I & $\mathbf{P}$ & $\mathbf{S}$ & Ext & Int \\
\hline Andaraí & 1 & - & - & - & 1 & - & - & 1 & - & 1 & 1 \\
\hline Mucugê & 13 & - & - & 8 & 5 & - & 1 & 10 & 2 & 13 & 13 \\
\hline Ituaçu & 3 & 2 & - & 2 & 3 & - & 3 & 2 & - & 5 & 5 \\
\hline Tanhaçu & 5 & 1 & 2 & 4 & - & - & 1 & 5 & - & 10 & 6 \\
\hline TOTAL & 22 & 3 & 2 & 14 & 9 & - & 5 & 18 & 2 & 29 & 25 \\
\hline
\end{tabular}

Legend: $I$ = illiterate $P$ = primary education $S=$ secondary education Ext = existing Int = interviewed Source: The authors

Data describing each of the sample towns and additional information regarding the waste pickers who work there are presented below.

Table 3 - Information about the sample cities

\begin{tabular}{|c|c|c|c|c|}
\hline LOCATION & ANDARAÍ & MUCUGE & ITUAÇU & TANAHÇU \\
\hline $\begin{array}{l}\text { URBAN } \\
\text { POPULATION }\end{array}$ & $\mathbf{7 , 7 7 3}$ & 4,180 & 6,569 & 8,290 \\
\hline IDENTITY & Chapada & Chapada & Sertão & Sertão \\
\hline TERRITORY & Diamantina & Diamantina & Produtivo & Produtivo \\
\hline $\begin{array}{l}\text { DISPOSAL } \\
\text { SITE }\end{array}$ & $\begin{array}{l}\text { Managed } \\
\text { landfill }\end{array}$ & $\begin{array}{l}\text { Waste recycling } \\
\text { and Composting } \\
\text { plant }\end{array}$ & Waste dump & Waste dump \\
\hline $\begin{array}{l}\text { NUMBER OF } \\
\text { WASTE PICKERS }\end{array}$ & 1 & 13 & 5 & 6 \\
\hline $\begin{array}{l}\text { CAVENGER'S } \\
\text { WORKING } \\
\text { AREA }\end{array}$ & City & $\begin{array}{l}\text { Waste recycling } \\
\text { and Composting } \\
\text { plant }\end{array}$ & $\begin{array}{l}\text { Waste dump } \\
\text { and Trade }\end{array}$ & $\begin{array}{l}\text { waste dump and private } \\
\text { recycling center }\end{array}$ \\
\hline
\end{tabular}

Source: The authors

\subsection{Data analysis}

All 25 interviewed waste pickers pick waste in the town where they live and have an average workload of 10 hours/day from Monday to Saturday. With the exception of the individual who works in Ituaçu as shop security guard at night and supplements his pay by working as a waste scavenger during the day, the interviewed waste pickers make a living solely from waste picking. Their workplaces vary, as shown in Table 3. The high workload of the waste pickers is in accordance with the working conditions found in other studies, such as Gutberlet (2007) and Medina (2000).

The age group with the highest number of waste pickers is the 18- to 34-year-old group. Regarding educational level, $72 \%$ of waste pickers have primary education, $20 \%$ are illiterate, and $8 \%$ have secondary education.

When asked if they would like to be part of a cooperative, 23 waste pickers answered yes, 10 of whom included specific conditions, namely, that there must be an environment of understanding among the workers in the cooperative and that the cooperative must be legitimate, i.e., it must guarantee equal rights to all participants. This need for legitimacy was also pointed out by Medina (2000).

The monthly compensation is variable. The group from Mucugê is an exception because these workers receive minimum wage from the municipal government, which is enhanced by an average monthly amount of BRL 300.00 from the sale of recyclable material. The other waste pickers have no employment relationship with the government. Fourteen of the respondents receive the Family Allowance (Bolsa Familia) benefit from the federal government. 
Table 4 presents the income ranges of the interviewed waste pickers and reveals that $80 \%$ of them have a monthly income below the minimum wage (BRL 724.00) in 2014.

Table 4 - Monthly income of waste pickers

\begin{tabular}{|lll|}
\hline $\begin{array}{l}\text { Amount in BRL/month from the sale of } \\
\text { recyclable material }\end{array}$ & $\begin{array}{l}\text { Number of waste } \\
\text { pickers }\end{array}$ & $\begin{array}{l}\text { Percentage } \\
(\%)\end{array}$ \\
\hline $300.00-500.00$ & 18 & 72 \\
\hline $501.00-724.00$ & 2 & 8 \\
\hline $725.00-900.00$ & 3 & 12 \\
\hline $901.00-1,200.00$ & 2 & 8 \\
\hline
\end{tabular}

Source: The authors

Self-employed waste pickers who receive monthly income higher than the minimum wage belong to small groups, such as the four individuals who work in the Ituaçu waste dump, or conduct their activities individually, like the metal scrap scavenger from Andaraí (Table 5). These results indicate that the higher the number of waste pickers in locations with small amounts of waste, the lower the waste pickers' per capita income. The mean monthly income of the waste pickers is BRL 518.00. Such a low income has been evidenced in other studies, including a few that were conducted in other developing countries, such as Aquino et al. (2009), Medina (2000), Giovannini and Kruglianskas (2008), Gutberlet (2007) and Medina (2000). Table 5 also displays the average income of the waste pickers at each city.

Table 5 - Monthly income range of waste pickers per city

\begin{tabular}{|l|l|l|l|l|l|l|l|l|}
\hline \multirow{2}{*}{$\begin{array}{l}\text { Amount in BRL/month } \\
\text { from the sale of recyclable } \\
\text { material }\end{array}$} & $\begin{array}{l}\text { Number } \\
\text { of } \\
\text { waste } \\
\text { pickers }\end{array}$ & $\begin{array}{l}\text { Number } \\
\text { of waste } \\
\text { pickers }\end{array}$ & $\begin{array}{l}\text { Number } \\
\text { TANHAÇU }\end{array}$ & \multicolumn{2}{|l|}{$\begin{array}{l}\text { ITUAÇU } \\
\text { pickers }\end{array}$} & $\begin{array}{l}\text { Number } \\
\text { of waste } \\
\text { pickers }\end{array}$ & $\%$ \\
\hline $\mathbf{3 0 0 . 0 0 - 5 0 0 . 0 0}$ & $\mathbf{3}$ & $\mathbf{5 0}$ & $\mathbf{2}$ & $\mathbf{4 0}$ & -- & -- & $\mathbf{1 3}$ & $\mathbf{1 0 0}$ \\
\hline $\mathbf{5 0 1 . 0 0 - 7 2 4 . 0 0}$ & $\mathbf{2}$ & $\mathbf{3 3}$ & -- & -- & -- & & -- & -- \\
\hline $\mathbf{7 2 5 . 0 0 - 9 0 0 . 0 0}$ & $\mathbf{1}$ & $\mathbf{1 7}$ & $\mathbf{1}$ & $\mathbf{2 0}$ & $\mathbf{1}$ & $\mathbf{1 0 0}$ & -- & -- \\
\hline 901.00-1,200.00 & -- & -- & $\mathbf{2}$ & $\mathbf{4 0}$ & -- & -- & -- & -- \\
\hline TOTAL & $\mathbf{6}$ & $\mathbf{1 0 0}$ & $\mathbf{5}$ & $\mathbf{1 0 0}$ & $\mathbf{1}$ & $\mathbf{1 0 0}$ & $\mathbf{1 3}$ & $\mathbf{1 0 0}$ \\
\hline Average Income per city & 539.50 & & 742.50 & & 812.50 & & 400.00 & \\
\hline
\end{tabular}

Source: The authors

The averageincome of waste pickers varies widely across the sample towns. Whereas the average monthly income for all waste pickers is BRL 518.50, the standard deviation is BRL 213.60. This is a relatively high standard deviation ( $42 \%$ of the mean) and indicates large income variations among waste pickers.

The selling price of recyclable materials is also variable and depends on the buyer (intermediary). Prices were collected and the mean selling prices were calculated for the sample area (data not shown here for brevity). All waste pickers from Mucugê sell the materials for the same fixed price, whereas the prices vary in the other towns.

Figure 1 presents the answers of the respondents when asked about the major needs for improving workplace conditions. The primary need was the use of personal protective equipment (PPE), especially boots, gloves, disposable masks, and uniforms. The interviewees from Mucugê singled out the necessity to improve the physical layout and transportation of the recycling center. These needs were identified by Lima (2010), in his study. 
Figure 1 - Major needs of waste pickers for improvement of workplace conditions

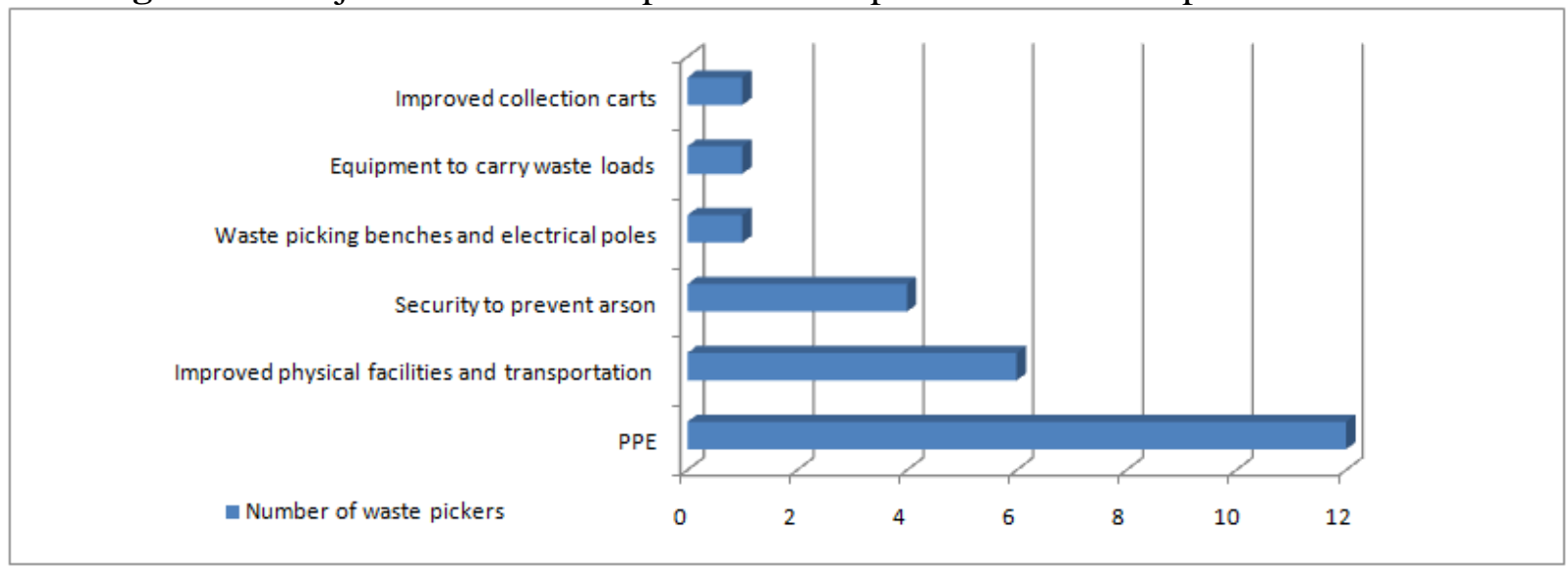

Source: The authors

Figure 2 lists respondents' demands related to the improvement of waste pickers' living conditions. Income growth and home ownership were given the highest priority. The respondents were asked about their single most important demand.

Figure 2 - Demands for improving the living conditions of waste pickers

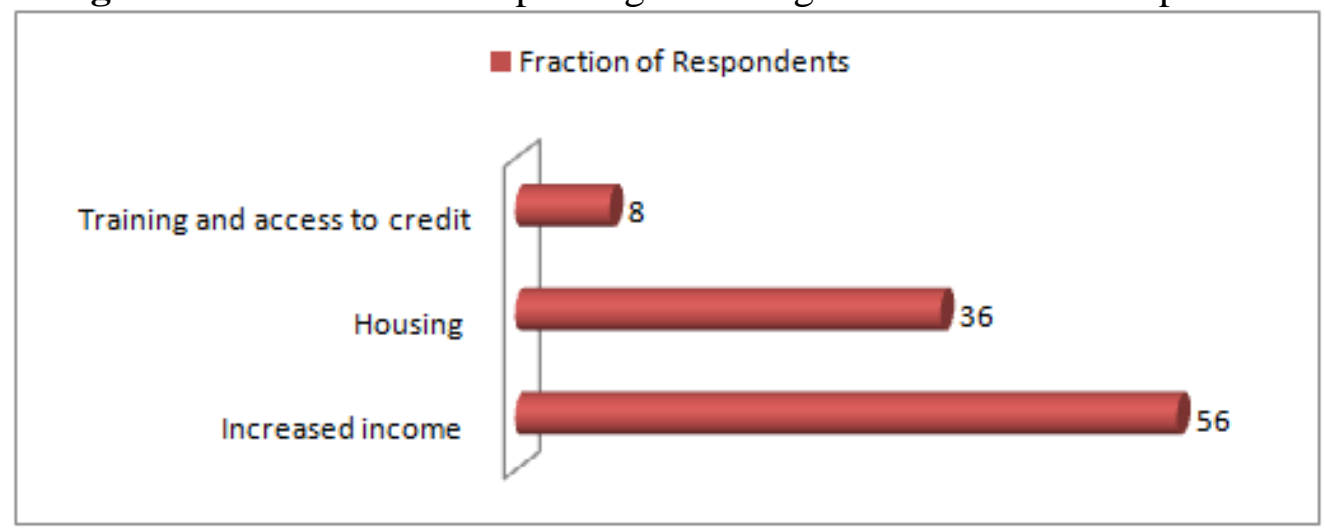

Source: The authors

The greatest needs of waste pickers to improve their living conditions are income growth and home ownership, according to $56 \%$ and $36 \%$ of the respondents, respectively. It is worth noting that $92 \%$ of waste pickers are willing to work in a formal organization, despite the negative experiences of several waste pickers at a cooperative they deemed "fake". It is also important to note that the majority of waste pickers require that the organization be a respectful workplace with a fair distribution of tasks and with fair pay.

\subsection{Proposed workforce management and estimated economic benefits for waste picking activities}

This section presents the waste-scavenger-workforce management model and the proposal for the RPSF. The projected investment, cost, and net income are also presented.

\subsubsection{Management model and proposal for the RPSF}

Considering the economic and social problems identified in the technical visits and interviews, including social isolation, an average monthly income below the minimum wage, and the precarious and hazardous - if not subhuman - conditions suffered by waste pickers who perform their activities at waste dumps, it is essential to design an alternative system that minimizes waste pickers' difficulties and allows picking to evolve into a work activity that receives the respect it deserves. 
Based on the requirements and guidelines of the PNRS, the experiences of recycling cooperatives in Brazil, and the wishes expressed by the waste pickers (which are supported by socioeconomic analysis), it is proposed that the RPSF is created and implemented at a regional level and that the development of RPSF is guided by both the principle of cooperativism and the concept of solidarity economy. The primary purpose of the RPSF is to add value to waste for the sole and direct financial benefit of the waste pickers.

The organizational structure of the RPSF is that of a second-degree cooperative formed by individuals and/or first-degree cooperatives. Recyclable waste will be supplied exclusively by individual cooperatives and individual waste pickers, who will receive a value-added payment corresponding to the amount and type of waste delivered.

The RPSF shall process and/or sell the solid waste collected by waste pickers (paper, cardboard, plastic, aluminum, steel, glass, and tetra pak packaging), turning it into raw material or finished product, thereby eliminating intermediaries from the process. Even waste that cannot be processed by the RPSF, such as aluminum and glass, obtain added value because they increase the RPSF's bargaining power by increasing business scale and reducing operating costs (especially transportation costs, because the logistics of a more structured business conducted on a larger scale is naturally more efficient).

It is estimated that a total of 10 individuals will be required to operate the RPSF, including five individuals working in operations and production, two individuals working as security guards, and three administrative support staff. All these workers will be singled out from the waste picker's population and appointed by the first-degree cooperatives. The administrative staff will also be elected by the representatives of the first degree cooperatives. Moreover, all individuals participating in the integrated system, including cooperative members, individual waste pickers, and RPSF workers, will be trained to conduct their respective activities. These workers will have formal jobs, receiving salaries and benefits, and will be dedicated full-time to their work in the facility. The projected annual cost with personnel is $\mathrm{R} \$ 368,494.80$, as shown later in figure 15. All other waste pickers will be paid proportional to their deliveries of solid waste, not having any formal ties with the RPSF. Therefore, the costs incurred in collecting the waste are not included, since waste pickers will be paid for their work based on the quantity of waste that they bring to the facility. The main objective of this part of the study is to detail the activities and structure of the RPSF and to calculate the financial gain that can be obtained by the waste pickers in case the RPSF is implemented and fulfills the purpose of buying the solid waste, processing it, and selling it for a better price. The individual future income of the waste pickers was not calculated. The fractional increase in their collective income was calculated instead. The selling price of solid waste was calculated based on the annual average market prices in 2015 .

\subsubsection{RPSF Physical Structure}

The physical structure designed for the pilot RPSF unit is an industrial warehouse with total area of $1,415 \mathrm{~m}^{2}$, with $1,273 \mathrm{~m}^{2}$ set aside for operational activities and $142 \mathrm{~m}^{2}$ for the administrative area.

\section{Geographic area defined as pilot}

The delimited region comprises 13 cities and involves two identity territories, as shown on table 6 . Three routes were planned for the waste collection. The maximum distance covered on a route is $155 \mathrm{~km}$.

This expanded area was chosen to engage a greater number of towns and to increase the scope of the project because the urban areas of the four sample towns are not densely populated and there is a technical need to scale up the supply to the waste processing machines. 
Table 6 - Towns that compose the area delimited for the management model

\begin{tabular}{lllll}
\hline $\mathbf{N}^{\mathbf{0}}$ & TOWN & $\begin{array}{l}\text { URBAN } \\
\text { POPULATION }\end{array}$ & $\begin{array}{l}\text { IDENTITY } \\
\text { TERRITORY }\end{array}$ & $\begin{array}{l}\text { HOUSEHOLD } \\
\text { INCOME INDEX }\end{array}$ \\
1 & Mucugê & $\mathbf{4 , 1 8 0}$ & 3 & 0.4596 \\
2 & Andaraí & 7,773 & 3 & 0.6471 \\
3 & Nova Redenção & 5,237 & 3 & 0.5607 \\
4 & Lençóis & 8,037 & 3 & 0.6128 \\
5 & Palmeiras & 5,239 & 3 & 0.5863 \\
6 & Ibicoara & 10,961 & 3 & 0.5583 \\
7 & Barra da Estiva & 10,404 & 3 & 0.4912 \\
8 & Ituaçu & 6,569 & 13 & 0.6057 \\
9 & Tanhaçu & 8,290 & 13 & 0.5566 \\
10 & Boninal & 4,607 & 3 & 0.6066 \\
11 & Piatã & 7,612 & 3 & 0.5940 \\
12 & Abaíra & 3,736 & 3 & 0.5400 \\
13 & Jussiape & 3,068 & 3 & 0.4856 \\
TOTAL & $\mathbf{8 5 , 7 1 3}$ & --- & $\mathbf{0 . 4 6 4 0}$ \\
CATAS ALTAS (Minas Gerais) & $\mathbf{4 , 2 4 0}$ & --- & \\
Source: & Demographic Census 2010 - IBGE & &
\end{tabular}

\section{Household income index per capita of 2000}

http://tabnet.datasus.gov.br/cgi/ibge/censo/cnv/giniba.def

\section{Projection of the gravimetric composition in the delimited area}

There is lack of reliable information on solid waste generation in Brazil. All official data and data from institutes and organizations are related to waste generation per capita for the country as a whole, for a region of the country, or even for a category of countries in which Brazil is included. There are no official data on waste generation or gravimetric composition for each city of the country. Among all of the studies reviewed, one stands out for making a consistent empirical assessment and determining both the gravimetric composition and the waste generation per capita for a small city. Despite being somewhat dated (it was published in 2003), the results of the study conducted in the city of Catas Altas, Minas Gerais state, were considered in this study for the projection of the gravimetric composition in the delimited area (Lange et al., 2003).

This estimate is especially valid because of the similarities between Catas Altas and the cities in the delimited area in terms of size, geography, socioeconomic and cultural characteristics, and climate. The household income per capita of Catas Altas was 0.4640 in 2000, which is very close to the income observed in the towns in this study during the same period (Table 7).

Thus, due to the lack of specific data for the towns in the delimited area, or for any town in the state of Bahia, the average waste generation per capita calculated for small cities in 2009 (fewer than 30000 inhabitants), i.e., $0.81 \mathrm{~kg}$ of waste/day, was adopted as the estimated waste generation per capita in the Bahia towns (Campos, 2012). The gravimetric composition is presented in Table 7.

Table 7 - Estimated gravimetric composition of waste for the delimited area

\begin{tabular}{ll} 
WASTE TYPE & $\begin{array}{l}\text { PERCENTAGE } \\
(\boldsymbol{\%})\end{array}$ \\
\hline Organic & 50 \\
\hline Others & 24 \\
\hline Plastic & 14 \\
\hline Paper & 8 \\
\hline Glass & 2 \\
\hline Metal & 2 \\
\hline Total & 100 \\
\hline
\end{tabular}

Source: Gravimetric composition of waste in Catas Altas, Minas Gerais 
The total urban population of the 13 towns in the delimited area is 85,713 inhabitants. Using 810 $\mathrm{g} /$ day as the average waste generation per capita, and a conservative estimate that only $58 \%$ of the total generation would actually be collected, $1,047,413 \mathrm{~kg}$ waste are collected per month.

Table 8 shows the projected monthly waste collection in the delimited area. The focus of this study is recyclable inorganic waste, which represents $26 \%$ of the total.

Table 8 - Projected generation of waste/month in the delimited area

\begin{tabular}{l|l|l}
\hline WASTE TYPE & PERCENTAGE (\%) & $\begin{array}{l}\text { ESTIMATED MONTHLY COLLECTED } \\
\text { WASTE (kg) }\end{array}$ \\
\hline Organic & 50 & $523,706.50$ \\
\hline Others & 24 & $251,379.12$ \\
\hline Plastic & 14 & $146,637.82$ \\
\hline Paper & 8 & $83,793.04$ \\
\hline Glass & 2 & $20,948.26$ \\
\hline Metal & 2 & $20,948.26$ \\
\hline Total & $\mathbf{1 0 0}$ & $\mathbf{1 , 0 4 7 , 4 1 3}$ \\
\hline
\end{tabular}

Source: The authors

\subsubsection{Identification of towns per collection route}

A total of 3 optimized roadmaps were created to reduce transportation time, distance traveled, and logistics costs. Note that the waste collection calculated for each route does not include the town of Mucugê because Mucugê is slated to host the pilot RPSF unit; thus, Mucugê's recyclable waste will be transported by the town's own selective collection truck. These calculations are not shown here for brevity. Table 9 shows the recyclable waste collection per route.

Table 9 - Daily and monthly recyclable waste collection per route

\begin{tabular}{l|l|l|l|l|l|l|l}
\hline \multirow{2}{*}{$\begin{array}{l}\text { Waste } \\
\text { Type }\end{array}$} & \multirow{2}{*}{$\begin{array}{l}\text { \% total } \\
\text { MSW }\end{array}$} & \multicolumn{6}{|l|}{ Amount of recyclable waste per day and month $(\mathbf{k g})$} \\
\cline { 3 - 8 } & & Route 1 & \multicolumn{3}{l}{ Route 2 } & \multicolumn{2}{l}{ Route 3 } \\
\cline { 3 - 8 } & & Day & Month & Day & Month & Day & Month \\
\hline Plastic & $\mathbf{1 4}$ & $2,383.5$ & 61,971 & $1,251.70$ & $32,544.20$ & $1,729.62$ & $44,970.12$ \\
\hline Paper & $\mathbf{8}$ & $1,362.0$ & 35,412 & 715.26 & $18,596.76$ & 980.35 & $25,489.10$ \\
\hline Glass & $\mathbf{2}$ & 340.5 & 8,853 & 178.81 & $4,649.06$ & 245.09 & $6,372.34$ \\
\hline Metal & $\mathbf{2}$ & 340.5 & 8,853 & 178.81 & $4,649.06$ & 245.09 & $6,372.34$ \\
\hline TOTAL & $4,426.50$ & $\mathbf{1 1 5 , 0 8 9}$ & $2,324.58$ & $\mathbf{6 0 , 4 3 9 . 0 8}$ & $3,200.15$ & $\mathbf{8 3 , 2 0 3 . 9 0}$ \\
\hline
\end{tabular}

Source: The authors

4.2.2 Estimated fleet size and collection frequency of recyclable waste by waste pickers

To calculate the size of the operating fleet, the following composition was considered: 


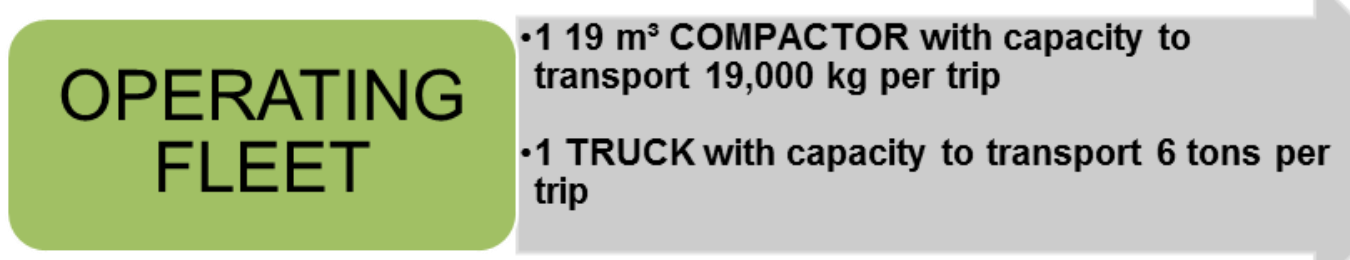

\section{SPECIFIC WASTE WEIGHT $\cdot 250 \mathrm{~kg}$ per $\mathrm{m}^{3}$ for compact load}

\section{COMPACTING DEGREE $\bullet 4 \times 1$}

The apparent specific mass of domestic wet waste (organic) considered by the Guidelines for the Preparation of Solid Waste Management Plans (Geres, 2012) is $250 \mathrm{~kg} / \mathrm{m}^{3}$ for loose waste and $600 \mathrm{~kg} / \mathrm{m}^{3}$ for compact waste. Because the specific mass for recyclable waste (dry) that will be collected and transported by the compactor was not found in the literature, $250 \mathrm{~kg} / \mathrm{m}^{3}$ was considered for compact recyclable waste.

Tables 10 and 11 show the number and frequency of monthly compactor and truck trips, respectively. The frequency was defined based on the amount of waste generated and the capacity of the trucks.

Table 10 - Collection frequency for the compactor

\begin{tabular}{l|l|l}
\hline & Waste(kg)/month & Number of travels/frequency \\
\hline $\mathbf{1}$ & 97,383 & 5 trips/month $=1 \mathrm{x}$ every 6 days \\
\hline $\mathbf{2}$ & 51,141 & 3 trips/month $=1 \mathrm{x}$ every 10 days \\
\hline $\mathbf{3}$ & 70,459 & 4 trips/month $=1 \mathrm{x}$ every 10 days \\
\hline TOTAL & $\mathbf{1 2}$ trips/month \\
\hline
\end{tabular}

Source: The authors

Table 11 - Collection frequency for the truck

\begin{tabular}{l|l|l}
\hline ROUTE & Waste(kg)/month & Number of trips/frequency \\
\hline $\mathbf{1}$ & 17,706 & 3 trips/month $=1 \mathrm{x}$ every 10 days \\
\hline $\mathbf{2}$ & 9,308 & 2 trips/month $=1 \mathrm{x}$ every 15 days \\
\hline $\mathbf{3}$ & 12,745 & 2 trips/month $=1 \mathrm{x}$ every 15 days \\
\hline TOTAL & $\mathbf{7}$ trips/month \\
\hline \multicolumn{2}{l}{ SOurce: } & The authors
\end{tabular}

Table 12 shows the distance traveled per vehicle and route to calculate the projected fuel cost.

Table 12 - Distance traveled per vehicle and route

\begin{tabular}{l|l|l}
\hline Route & Compactor & Truck \\
\hline $\mathbf{1}$ & $5 \times 298.50=1,492.50$ & $3 \times 298.50=895.5$ \\
\hline $\mathbf{2}$ & $3 \times 286.90=860.70$ & $2 \times 286.90=573.8$ \\
\hline $\mathbf{3}$ & $4 \times 310.70=1,242.80$ & $2 \times 310.70=621.4$ \\
\hline
\end{tabular}

Source: The authors

\subsubsection{Calculation of financial benefits for waste pickers}

To calculate the financial benefits obtained by waste pickers who provide services to the RPSF, all investments and costs related to the venture were considered, and the potential percentage increase in scavenger income derived from the processing of recyclable waste was calculated.

\subsubsection{Investments}

Revista de Gestão Social e Ambiental - RGSA, São Paulo, v. 11, n. 1, p. 02-15, jan./abr. 2017. 
The initial investment includes costs related to facilities, vehicles, equipment, furniture, stock, and any other items required to start the business.

In addition to fixed investments, the investment required to implement the RPSF (Table 13) includes circulating investments for working capital and other initial expenses. Working capital was estimated to ensure that the RPSF could pay suppliers (cooperative members or individual waste pickers) immediately after material delivery (recyclable waste), starting with the first batch, thereby meeting the trading needs of this class of workers.

All fixed investment items were quoted in the retail market by service providers (vehicle insurance companies) and suppliers (machines, equipment, and vehicles). At least three quotes were obtained for each item.

Warehouse building costs were calculated for a complete budget and include infrastructure, superstructure, electrical, hydraulic, and sanitary facilities costs.

The initial investment for the pilot RPSF project is expected to be obtained through a government grant from the Regional Development and Action Company's (Companhia de Desenvolvimento e Ação Regional - CAR) Productive Bahia (Bahia Produtiva) Program.

Table 13 - Investments for implementation of the RPSF

\begin{tabular}{l|l}
\hline INVESTMENTS & Amount in BRL \\
\hline Fixed & \\
\hline Construction & $627,824.40$ \\
\hline Machines and equipment & $423,652.00$ \\
\hline Vehicles & $267,600.00$ \\
\hline Insurance + vehicle plates & $24,320.00$ \\
\hline Treatment plant & $18,349.00$ \\
\hline Tooling & $16,320.13$ \\
\hline Furniture and appliances & $16,086.20$ \\
\hline total & $\mathbf{1 , 3 9 4 , 1 5 1 . 7 3}$ \\
\hline Circulating & \\
\hline Working capital & $198,484.80$ \\
\hline Other initial expenses & $10,000.00$ \\
\hline total & $\mathbf{2 0 8 , 4 8 4 . 8 0}$ \\
\hline TOTAL INVESTMENT & $\mathbf{1 , 6 0 2 , 6 3 6 . 5 3}$ \\
\hline
\end{tabular}

Source: The authors

\subsubsection{Costs}

Table 14 lists the operating and administrative costs and the reserve fund. The calculations relating to fuel, fleet maintenance, tires, and depreciation of the operating fleet were based on the costs of a multinational company with strong sales logistics. For electricity and water, information on machine consumption provided by manufacturers and cost data provided by utility companies were considered.

The cost composition of the RPSF includes estimates for three items deemed necessary for the continuity of investment: operating fleet depreciation, machine depreciation, and the reserve fund. This reserve fund is to be created in order to ensure the sustainability of the project and of the business.

For the "internal" labor item, a total of 10 individuals was estimated: five individuals working in operations/production, two security guards, and three administrative support staff. With respect to skilled labor, the hiring of accounting services was considered. It is important to point out that all workers, including the administrative staff, will be comprised of personnel chosen from the population of waste pickers and properly trained to perform their duties. 
Table 14 - RPSF costs projected for the first year of operation

\begin{tabular}{l|l|l}
\hline COSTS & Amount (BRL) \\
\hline OPERATING COSTS & & \\
\hline Fuel & & $29,343.36$ \\
\hline Fleet maintenance & & $8,188.80$ \\
\hline Tires & & $12,965.64$ \\
\hline Electricity & $6,500.00$ \\
\hline Water & & $3,360.00$ \\
\hline Secondary materials & $18,000.00$ \\
\hline Operating fleet depreciation & $25,232.04$ \\
\hline Machine depreciation & & $42,365.20$ \\
\hline Total & & $\mathbf{1 4 5 , 9 5 5 . 0 4}$ \\
\hline ADMINISTRATIVE COSTS & \\
\hline Others (cleaning, internet, telephone) & $28,800.00$ \\
\hline Administrative and operating labor & $143,328.00$ \\
\hline Social security taxes & & $85,966.80$ \\
\hline Skilled labor & $96,000.00$ \\
\hline Office supplies & $14,400.00$ \\
\hline Total & & $\mathbf{3 6 8 , 4 9 4 . 8 0}$ \\
\hline RESERVE FUND & $\mathbf{6 7 , 5 9 7 . 2 4}$ \\
\hline TOTAL COSTS & $\mathbf{5 8 2 , 0 4 7 . 0 8}$ \\
\hline
\end{tabular}

Source: The authors

\subsubsection{Projected increase in net income}

The income increase calculation identifies the percent increase in waste pickers' incomes derived from the sale of waste processed by the RPSF. The income was projected based on $100 \%$ of the combined annual waste generation of all 13 cities included in the study.

Table 15 - Estimated income from the RPSF

\begin{tabular}{l|l|l|l}
\hline Waste type & $\begin{array}{l}\text { Selling price } \\
(\text { BRL) }\end{array}$ & $\begin{array}{l}\text { Projected } \\
\text { waste/month } \\
(\mathbf{k g})\end{array}$ & $\begin{array}{l}\text { Estimated monthly } \\
\text { income (BRL) }\end{array}$ \\
\hline Plastic & 3.00 & $146,637.82$ & $439,913.46$ \\
\hline Paper & 0.15 & $83,793.04$ & $12,568.96$ \\
\hline Glass & 0.10 & $20,948.26$ & $2,094.83$ \\
\hline Metal & 2.00 & $20,948.26$ & $41,896.52$ \\
\hline \multicolumn{2}{|l}{} & $496,473.77$ \\
\hline
\end{tabular}

Source: The authors

The selling prices of the materials were obtained from the recycling market in August 2014.

Table 16 - Estimated scavenger income without waste processing

\begin{tabular}{l|l|l|l}
\hline Waste type & $\begin{array}{l}\text { Selling price } \\
(\text { BRL) }\end{array}$ & $\begin{array}{l}\text { Projected } \\
\text { waste/month } \\
(\mathbf{k g})\end{array}$ & $\begin{array}{l}\text { Estimated monthly } \\
\text { income (BRL) }\end{array}$ \\
\hline Plastic & 1.00 & $146,637.82$ & $146,637.82$ \\
\hline Paper & 0.10 & $83,793.04$ & $8,379.30$ \\
\hline Glass & 0.05 & $20,948.26$ & $1,047.41$ \\
\hline Metal & 1.50 & $20,948.26$ & $31,422.39$ \\
\hline Total & $187,486.92$ \\
\hline
\end{tabular}

Source: The authors

The selling prices of the materials are the mean prices surveyed in the four sample cities. To calculate the percent increase in income, the annual net income obtained through the sale of waste processed by the RPSF was compared to the annual net income obtained through the sale of waste not processed by the 
RPSF (i.e., the sale of waste by waste pickers directly to intermediaries). A $10 \%$ excise tax and $17 \%$ valued added-tax (VAT) were deducted from gross income.

Table 17 presents the calculated increase in waste scavenger income. Even considering the costs related to the incorporation of the waste picking business, such as taxes, depreciation, and the reserve fund, the projected increase in income $-67.44 \%$ - is substantial.

The enhanced financial viability of the waste picking activities and the potential improvement of the waste pickers' working conditions by means of organized labor, solidary economy and cooperatives was also singled out by authors such as Gutberlet (2007), Medina (1998), Lima (2010), and especially Gomes and Nóbrega (2005).

The proposed second-degree cooperative helps to address challenges identified by Demajorovic et al. (2014), such as improving managerial processes and difficulties to achieve enough scale. The direct commercialization will enable waste pickers to achieve better selling prices for their products and will increase their chances of survival in the long term (Jesus and Barbieri, 2013). It is possible to state that the cooperative will play a significant role in the reverse channels of urban solid waste, and will contribute to minimize environmental problems and enhance the socio-economic conditions of waste pickers (Santos, 2012). The cooperative can bring advantages such as increasing the lifespan of waste dumps; reducing the incorrect destination of solid waste; reducing energy consumption; reducing the extraction of raw materials from nature, besides enhacing the work conditions of waste pickers (Souza et al., 2012).

Table 17 - Projected increase in waste scavenger income

\begin{tabular}{|c|c|c|}
\hline \multicolumn{3}{|c|}{ PROJECTED INCREASE (BRL) } \\
\hline COMPOSITION & $\begin{array}{r}\text { WITH } \\
\text { PROCESSING }\end{array}$ & $\begin{array}{l}\text { WITHOUT } \\
\text { PROCESSING }\end{array}$ \\
\hline Estimated monthly income & $496,473.77$ & $187,486.92$ \\
\hline Annual gross income & $5,957,685.24$ & $2,249,843.04$ \\
\hline - 27\% taxes (Excise and VAT) & $1,608,575.01$ & -------- \\
\hline - Annual costs & $582,047.08$ & -------- \\
\hline Annual net income & $3,767,063.15$ & $2,249.843 .04$ \\
\hline DIFFERENCE & \multicolumn{2}{|c|}{$\begin{array}{l}\text { BRL 1,517,220.11 } \\
\text { corresponding to } 67.44 \% \text { increase }\end{array}$} \\
\hline
\end{tabular}

Source: The authors

\section{CONCLUSIONS}

The aim of this study was to propose a management model that would allow waste pickers to obtain both increased economic benefits and improved working conditions. Thus, an analysis of the socioeconomic conditions of waste pickers was performed in four small cities in the state of Bahia, and the disparate working conditions of waste pickers were revealed.

When the collection site is a waste dump or a private recycling center, waste pickers do not wear PPE or uniforms and thus are totally vulnerable to the unhealthy and highly hazardous conditions of waste collection activities. It was found that waste pickers have a heavy workload and that their work involves tasks that are very physically demanding. The average workload is 10 hours/day, from Monday to Saturday.

The monthly income of $80 \%$ of the interviewed waste pickers and the mean monthly income of all waste pickers (BRL 518.50) are both lower than the minimum wage. None of the respondents belongs to any workers' union; rather, they depend on intermediaries who establish the selling rules and the waste prices.

Recognition of waste picking activity and its inclusion in the solid waste management system are both provided by Brazilian law. Therefore, with fair and efficient management, the potential improvement of the waste pickers' quality of life is significant. In this regard, the first item on the agenda should be improvements to waste pickers' basic working conditions, including the provision of PPE and uniforms.

This study also contributes evidence regarding the need for a formal organizational structure for waste pickers' activities conducted through cooperatives and associations, because such a structure will foster better working and living conditions. Moreover, although it was not the focus of this study, the findings suggest that the proposed organization of waste pickers' activities and the creation of the RPSF will have effects that go beyond improvements in waste pickers' socioeconomic conditions, including increased 
self-esteem and self-worth, a feeling of belonging to a group, the establishment of a professional identity, and increased social awareness.

The study shows the need to add value to MSW by means of processing techniques that require relatively low investment but offer significant gains. The study also demonstrates that even accounting for the depreciation of the fleet and machinery and for the creation of a reserve fund for maintenance needs, the waste processed and sold at the RPSF could increase waste pickers' income by $67.44 \%$. This income growth would allow tangible improvements to waste pickers' quality of life, in terms of both income and occupational safety.

This study can guide practices in other countries that have realities that are similar to those in Brazil, of accelerated urbanization without adequate planning for solid waste management, added to the strong presence of waste pickers which, through their social vulnerability, must be included in the system.

The estimated initial investment of BRL 1,602,636.53 is relatively small considering the number of municipalities involved (13), the beneficiary population, and the benefits that will be obtained by waste pickers in the long term. It is expected that the proposals presented herein can serve as a model for other small cities with similar conditions. It is important to point out that the main limitation of the business model presented here is the necessity of an initial investment from the government for the implementation of the project. Even though the funding for the present project has already been ensured, other projects may suffer from insufficient funds.

\subsection{Limitations Of The Study}

One of the main limitations of this study is the use of a gravimetric waste composition that is not specific to the cities studied. There is a lack of studies related to gravimetric composition and per capita waste generation in small cities, both in the state of Bahia and at the national level.

Another limitation is that the projected income of waste pickers is estimated, due to the lack of control over the amount of waste sold per waste type.

\subsection{Recommendations For Future Studies}

A suggested topic for future studies is the calculation of waste generation per capita and the gravimetric composition of waste generated in cities of different sizes in the same region, which would extend the analysis of waste pickers' socioeconomic conditions. In particular, the authors consider it important that the socioeconomic conditions of waste pickers in small towns be described at the national level.

Research regarding waste pickers' participation in the entire recycling supply chain, taking into account the workers' fight for vertical integration, is also suggested.

\section{REFERENCES}

Abrelpe (Brazilian Association Of Urban Cleaning And Waste Management Companies) (2013): Panorama dos Resíduos Sólidos no Brasil. São Paulo.

Abrelpe (Brazilian Association Of Urban Cleaning And Waste Management Companies) (2012): Panorama dos Resíduos Sólidos no Brasil. São Paulo.

Afon, A.A.(2012):Survey of operational characteristics, socioeconomic and health effects of picking activity in Lagos, Nigeria. Waste Management \& Research 30(1) 664-671.

Aquino, I. F.; Castilho Jr., A. B.; Pires, T. S. de L. (2009): A organização em rede dos catadores de materiais recicláveis na cadeia produtiva reversa de pós-consumo da região da grande Florianópolis: uma alternativa de agregação de valor. Gestão \& Produção, São Carlos, v. 16, n. 1, p.15-24, Jan.-Mar..

Arantes, B. O.; Borges, L. de O. (2013): Catadores de materiais recicláveis: cadeia produtiva e precariedade. Arquivos Brasileiros de Psicologia, Rio de Janeiro, v. 65, n. 3. 
Brazil. Act 12.305/2010 (2010): Established the National Solid Waste Policy (PNRS); amends Act no. 9.605 of February 12, 1998 and provides other measures. D.O.U (Brazilian Federal Official Gazette) of August 3 2010.

Brazil (2010). Decree $n^{\circ} 7.404$ of December 23, 2010. Sets forth Act 12,305. Available at: http://www.planalto.gov.br/ccivil_03/_ato2007-2010/2010/Decreto/D7404.htm. Accessed on: June 10, 2016. Campos, H.K.T. (2012): Renda e evolução da geração per capita de resíduos sólidos no Brasil. Eng Sanit Ambient, v.17, n.2, 171-180.

Carvalho, A. M. R. De; Ladeia, C. R. (2011): Trabalho e sociabilidade: a formação de uma rede de catadores no oeste paulista. VII Encontro Internacional De Economia Solidária, São Paulo.

Demajorovic, J., Caires, E. F., Gonçalves, L. N. S., \& Silva, M. J. C. (2014). Integrando empresas e cooperativas de catadores em fluxos reversos de resíduos sólidos pós-consumo: o caso Vira-Lata. Cadernos EBAPE.BR, 12(Edição Especial), 513-513.

Ferri, G.L.; Chaves, G.L.D.; Ribeiro, G.M.(2015); Reverse logistics network for Municipal solid waste management: The inclusion of waste pickers as a Brazilian legal requirement. Waste Management, v. 40, p. 173-191.

GERES (Gestão de Resíduos Sólidos - Solid Waste Management) (2012): Planos de Gestão de Resíduos Sólidos: Manual de Orientação. Available at:

http://www.mma.gov.br/estruturas/182/_arquivos/manual_de_residuos_solidos_28_03_182.pdf . Accessed on February 18, 2016.

Giovannini, F.; Kruglianskas, I. (2008): Fatores críticos de sucesso para a criação de um processo inovador sustentável de reciclagem: um estudo de caso. Revista de Administração Contemporânea, v. 12, n. 4, p. 931951.

Gomes, H. P.; Nóbrega, C. C. (2005): Economic viability study of a separate household waste collection in a developing country. Waste Management, v. 7, p. 116-123.

Gonçalves-Dias, S.; Lopes, F. (2009): Catadores: uma perspectiva de sua inserção no campo da indústria de reciclagem. 2009. Dissertation (PhD in Environmental Science) - University of São Paulo, São Paulo.

Available at: http://www.teses.usp.br/teses/disponiveis/90/90131/tde-25102010-231013/. Accessed on: April $2,2016$.

Gutberlet, J. (2007): Empowering collective recycling initiatives: Video documentation and action research with a recycling co-op in Brazil. Resources, Conservation and Recycling, v. 52, p.659-670.

IBGE (Brazilian Institute Of Geography And Statistics) (2010): Demographic census - 2010. IBGE System of Automatic Retrieval (Sistema IBGE de Recuperação Automática - SIDRA). Rio de Janeiro.

Jesus, F. S. M., \& Barbieri, J. C. (2013). Atuação de cooperativas de catadores de materiais recicláveis na logística reversa empresarial por meio de comercialização direta. Revista de Gestão Social e Ambiental, 7(3), 20-36.

Ketele, J; Roegiers, X. (1993): Méthodologie du recueil d'informations: fondements de méthodes d'observations de questionaires, d'interviews et d'étude de documents. 2. ed. Bruxelles: De Boeck Université. p. 99.

Lange, L. C., Simões, G. F.; Ferreira, C. F. A. (2003): Aterro sustentável: um estudo para a cidade de Catas Altas, MG [Sustainable landfill: a study for the city of Catas Altas, Minas Gerais]. In: Castilhos Junior, A. B.(Editor). Resíduos sólidos urbanos: aterro sustentável para municípios de pequeno porte. Rio de Janeiro: ABES, RiMa, p.43-197. Available at: http://www.finep.gov.br/prosab/livros/ProsabArmando.pdf. Accessed on: October 26, 2016.

Leite, M. P. (2011): Cooperativas e trabalho: um olhar sobre o setor de reciclagem e as fábricas recuperadas em São Paulo. In: GEORGES, I. P.H.; LEITE, M. de P. (Org.) Novas configurações do trabalho e economia solidária. São Paulo: Annablume, FAPESP. 
Lima, J. C. (2010): Cooperativas de reciclagem de lixo no Brasil: a autogestão da pobreza. (mimeo).

Mazzei, B. B.; Crubellate, J. M. (2011): Autogestão em empreendimentos econômicos solidários: um estudo comparativo de casos em cooperativas de reciclagem de lixo de Maringá- PR. Revista Inteligência Organizacional, Mariana/MG, v.1, n.1.

Medina, M. (1998): Border scavenging: a case study of aluminum recycling in Laredo, TX and Nuevo Laredo, Mexico. Resources, Conservation and Recycling, v. 23, p.107-126, 1998.

Medina, M. (2000): Scavenger cooperatives in Asia and Latin America. Resources, Conservation and Recycling, v. 31, p.51-69.

Inspiração Magazine (2013): Construindo soluções para o futuro. Cata Ação Program, Walmart Institute and GIRAL viveiro de projetos. Available at:

http://www.cataacao.org.br/wpcontent/uploads/2013/09/969_PublicaAAoInspiraAAopdf.pdf . Accessed on: June 28, 2016.

Rufino, S. (2002): Qualidade de vida de trabalhadores de cooperativas autogestionárias. XXII Encontro Nacional De Produção. Curitiba.

Santos, J. G.(2012). A Logística Reversa como ferramenta para a sustentabilidade: um estudo sobre a importância das cooperativas de reciclagem na gestão dos resíduos sólidos urbanos. Reuna, 17(2), 81-96.

Saraiva Júnior, A. F.; Costa, R. P. Da; Pinto, J. C. (2009): Economia solidária no Brasil: distribuição dos excedentes em uma cooperativa de serviços de industrialização. Xxix Encontro Nacional De Engenharia De Produção, Salvador, Brazil.

Seplan (Department Of Planning) (2007): Comissão Estadual dos Territórios - CET. State Government of Bahia.

Sedur Secretaria De Desenvolvimento Urbano Do Estado Da Bahia (2014): . Glossário de Resíduos Sólidos [Solid Waste Glossary].

Sei (Superintendence Of Economic And Social Studies Of Bahia) (2006):. Bahia em Síntese]. IDE/IDS índices municipais de desenvolvimento econômico e social (EDI/SDI - Municipal economic and social development indices). Salvador, Brazil.

Souza, M. T. S., Paula, M. B., \& Souza-pinto, H. (2012). O papel das cooperativas de reciclagem nos canais reversos pós-consumo. Revista de Administração de Empresas, 52(2), 246-262.

Tirado-Soto, M.M. ; Zamberlan, F.L.. Networks of recyclable material waste-picker's cooperatives: An alternative for the solid waste management in the city of Rio de Janeiro. Waste Management.v.33, p. 20042012, 2013.

Wirth, I. G. (2010): As relações de gênero em cooperativas populares do segmento da reciclagem: um caminho para a construção da autogestão? 2010, 226 f.. Dissertação (Mestrado em Educação), Faculdade de Educação, Universidade Estadual de Campinas, Campinas (SP).

Data da submissão: 07/11/2016

Data de aceite: 06/04/2017 